\title{
ANITA KŁOS
}

iD https://orcid.org/0000-0003-4865-0013

Uniwersytet Marii Curie-Skłodowskiej w Lublinie

anita.klos@poczta.umcs.lublin.pl

\section{PRZEKŁADY NIEBEZPOŚREDNIE W POLSKO- -WŁOSKICH RELACJACH LITERACKICH W DWUDZIESTYM WIEKU. REKONESANS}

\begin{abstract}
Indirect Translation in the 20th-Century Polish-Italian Intercultural Exchange: A Reconnaissance

The aim of the paper, which brings together the results of a pretiminary research, is to provide an overview of selected issues and textual practices related to indirect translation in the Polish-Italian intercultural exchange in the 20th century. In Polish literary translation studies, the significance of indirect translation has been seriously undervalued, especially in research on literary translation from Polish as a source language. Many classical works prominent of Polish authors (e.g. Witold Gombrowicz, Czesław Miłosz, Stanisław Lem) were published in Italy as a result of indirect translation via one of the "central" languages, usually French or English, or by a bilingual team of translators. After discussing main terminological and methodological issues, the study presents two "microhistorical" examples - La casa delle donne: Zofia Nałkowska's Dom kobiet translated in 1930 by Sibilla Aleramo via intermediary translations into French and Italian, and Witold Gombrowicz's Ferdydurke, translated into Italian in 1961 by Sergio Miniussi via French and Spanish, under the supervision of Konstanty A. Jeleński. These two cases, exemplify different text typologies and practical approaches to the translation process.
\end{abstract}

Keywords: indirect translation, reception, Polish literature, Zofia Nałkowska, Sibilla Aleramo, Witold Gombrowicz

Słowa kluczowe: przekład niebezpośredni, recepcja, literatura polska, Zofia Nałkowska, Sibilla Aleramo, Witold Gombrowicz 


\section{Zły obyczaj? Wprowadzenie}

„Zaryzykowałbym wręcz stwierdzenie, że żadne historycznie zorientowane studium nad kulturą, w której kiedykolwiek praktykowano przekład niebezpośredni, nie może sobie pozwolić na zignorowanie tego zjawiska i niepodjęcie studiów nad jego znaczeniem" - pisał Gideon Toury w Descriptive Translation Studies and Beyond (Toury 1995: 130). Rozdział siódmy słynnego studium, A Lesson from Indirect Translation, poświęcił literackim przekładom z drugiej ręki (second-hand translations), przedstawiając w nim historyczny zarys dotyczący praktyk niebezpośrednich w literaturze tłumaczonej na język hebrajski od końca XVIII wieku przez kolejne dwa stulecia (Toury 1995: 129).

Niemal współcześnie z książką Toury’ego, w 1994 roku, ukazał się tom pod redakcją Pietra Marchesaniego prezentujący bilans recepcji literatury polskiej we Włoszech w wieku dwudziestym (Marchesani 1994). Wyraźnie pobrzmiewają w nim narzekania na powszechność „,pośledniego sortu zjawiska retranslacji (ritraduzione)” oraz „retranslatorów zupełnie niezorientowanych polonistycznie" (Raffo 1994: 80-81). Sam Marchesani w rozdziale poświęconym recepcji prozy w latach 1945-1990, opartym na badaniach bibliograficznych przeprowadzonych wraz z Marcellem Piacentinim, ubolewał, iż nawet w drugiej połowie XX wieku, mimo rozwoju włoskiej polonistyki i zdecydowanego powiększenia się grona tłumaczy zdolnych tłumaczyć bezpośrednio z oryginału, „nie zaniknął zły obyczaj (pessima usanza) - zarezerwowany zwykle dla literatur cieszących się mniejszym prestiżem - tłumaczenia z przekładów na inne języki” (Marchesani 1994a: 30). Nawet jeśli ograniczymy się do korpusu tłumaczeń prozatorskich przywołanych w artykule włoskiego badacza, na 121 wymienionych pozycji (powieści i zbiorów opowiadań, bez antologii tekstów różnych autorów i reedycji) dziewięć przetłumaczono za pośrednictwem translacji na inne języki obce, zaś 23 to efekt pracy zespołów tłumaczy, najczęściej dwujęzycznych „tandemów” (Zaboklicka 2013) złożonych z pary rodzinnych użytkowników języka włoskiego i polskiego. Wśród tłumaczeń będących rezultatem niebezpośrednich translacji są tak ważne w historii polskiej literatury utwory jak Zniewolony umysł Czesława Miłosza (Miłosz 1955), Inny świat Gustawa Herlinga-Grudzińskiego (Herling-Grudziński 1958), Austeria Juliana Stryjkowskiego (Stryjkowski 1984), Powrót z gwiazd Stanisława Lema (Lem 1963), jak również klasyczne pozycje literatury non-fiction: 
między innymi Zdążć przed Panem Bogiem Hanny Krall (Krall, Edelman 1985) czy Cesarz Ryszarda Kapuścińskiego (Kapuściński 1991). Do tego dodać należy przekłady prozy wydane we Włoszech przed 1945 rokiem (m.in. Niedobrej miłości Zofii Nałkowskiej; Nałkowska 1944) i po roku 1990 (np. Cyberiady Lema; Lem 1995) oraz liczne translacje utworów dramatycznych (m.in. włoskie wersje Matki Witkacego, Ślubu i Operetki Gombrowicza; Witkiewicz 1970, Gombrowicz 1967 i Gombrowicz 1968) i poetyckich (jak przekłady liryków Mickiewicza dokonane przez noblistę Salvatore Quasimoda; Quasimodo 1956: 49-52). Przekład niebezpośredni praktykowano również $\mathrm{w}$ relacji odwrotnej, w translacjach włoskich dzieł literackich w Polsce, zwłaszcza w dziedzinie teatru i poezji (np. Vasari [1926]; zob. Strożek 2012: 180-191), choć w mniejszej skali, którą przekonująco da się wytłumaczyć różnicą pozycji obu języków w opisanym przez Johana Heilbrona międzynarodowym systemie przekładowej wymiany, w której włoski klasyfikowany jest jako język „,semi-centralny”, polski natomiast jako „(semi)-peryferyjny” (por. Heilbron 2010). Niebezpośrednie translacje jeszcze z pewnością w latach 60 . XX wieku wykonywane były przez uznanych autorów i akceptowane przez prestiżowe wydawnictwa jak Państwowy Instytut Wydawniczy (Quasimodo 1961), wspierane przez polskie związki literackie i dyplomację kulturalną. Na przykład w trakcie przygotowań do Roku Mickiewiczowskiego w 1955 roku Związek Literatów Polskich zlecił przygotowanie przekładów filologicznych poezji wieszcza na główne języki europejskie, w tym włoski, które za pośrednictwem polskich ambasad rozesłano do zagranicznych poetów poproszonych o stworzenie nowych tłumaczeń (Kłos 2018). Czas zatem najwyższy zadać pytania o rolę przekładu niebezpośredniego w wymianie literackiej między Polską a Włochami, do „pytań pomocniczych" wskazanych przez Toury'ego ${ }^{1}$ dodając kolejne, wynikające z rozwoju przekładoznawstwa, chociażby te zaczerpnięte ze starożytnej retoryki i zaproponowane przez Lievena D'hulsta na użytek uniwersalnej historiografii przekładu: Quis? („Kto?”), Quid? („Co?”), Ubi?

${ }^{1}$ „W tłumaczeniu jakich języków źródłowych/gatunków tekstowych/okresów literackich (itp.) [przekład niebezpośredni] jest dozwolony/niedopuszczalny/tolerowany/preferowany? Jakie języki pośredniczące są dozwolone/niedopuszczalne/tolerowane/preferowane? Czy zwykle/obowiązkowo zaznacza się, że przekład został zapośredniczony, czy też fakt ten jest ignorowany/ukrywany/wypierany? Czy jeśli ta informacja się pojawia, to czy do wiadomości podawane są także języki pośredniczące?” (Toury 1995: 130). O ile nie zaznaczono inaczej, cytaty podano w thumaczeniu autorki. 
(„Gdzie?”), Quibus auxiliis? (,Z czyim udziałem?”), Cur? („Dlaczego?), Quomodo? (,Jak?”), Quando? („Kiedy?”) (D’hulst 2010: 399).

W niniejszym tekście przyjmuję szeroką definicję przekładu niebezpośredniego jako „translacji translacji” (Assis Rosa, Pięta, Bueno Maia 2017: 119-121), która nie wskazuje liczby języków biorących udział w procesie przekładu, a zatem jednym z jego etapów może być przekład wewnątrzjęzykowy (por. klasyfikacja typologiczna przekładu niebezpośredniego w: Assis Rosa, Pięta, Bueno Maia 2017: 121-122 i Washbourne 2013: 612-614). Takie ujęcie umożliwia włączenie w obszar rozważań zarówno translacji przygotowywanych na podstawie przekładu filologicznego na język docelowy, efektów pracy dwujęzycznych zespołów tłumaczy, która z reguły polega na przygotowaniu wstępnej wersji w języku docelowym przez użytkownika języka źródłowego i negocjowaniu przez obu tłumaczy ostatecznego kształtu tekstu w serii prze-pisań (Zaboklicka 2013), jak również wszelkich translacji kompilacyjnych, łączących na różne sposoby tłumaczenie wewnątrz- i międzyjęzykowe.

Przekłady niebezpośrednie, choć niezmiennie obecne w praktyce translatorskiej i oddziałujące na historię kultury (dość wspomnieć casus Biblii), długo budziły marginalne zainteresowanie badaczy przekładu lub były wręcz ignorowane: skoro przez stulecia przekład postrzegany był jako niedoskonała z definicji kopia oryginału, niegodna krytycznego i naukowego zainteresowania, to przekład powstały na podstawie innego przekładu jawił się jako fakt nieomalże wstydliwy (St André 2009: 230). Od studium Toury'ego (Toury 1995) i publikacji Yvesa Gambiera (Gambier 1994) sytuacja zaczęła się zmieniać, a po roku 2000 studia nad przekładem niebezpośrednim nabierały coraz bardziej systematycznego charakteru (por. Pięta 2017). Potwierdzają to artykuły opublikowane niedawno w dwóch kolejnych numerach czasopisma „Translation Studies” (nr 10 z 2017 i nr 11 z roku 2018), które podsumowują stan badań i główne problemy metodologiczne studiów nad przekładem niebezpośrednim, upominają się o dowartościowanie jego roli w historii przekładu i współczesnej wymianie literackiej (Alvstad 2017), ale też, w serii case studies (np. Ivaska, Paloposki 2018), pokazują, jak istotne i ciekawe pole otwiera refleksja nad tym rodzajem thumaczenia. Sprzyja jej-dobitne w pracach operujących koncepcją ,głosów” w przekładzie (zob. m.in. Alvstad, Greenall, Jansen, Taivalkoski-Shilov 2017) - kwestionowanie tezy, że tekst docelowy jest jednostkowym dziełem tłumacza, w pełni odpowiadającego za jego ostateczną formę. Hanne Jansen i Anna Wegener mówią wręcz o „Zwielokrotnionym autorstwie przekładu” (multiple translatorship), 
upominając się o uwzględnienie w badaniach pozatekstowych (extratextual) głosów wydawców, redaktorów, korektorów, cenzorów, rozmaitych doradców, autorów paratekstów i recenzji, którzy dzieło tłumacza poddają dalszym transformacjom i kształtują jego recepcję (Jansen, Wegener 2013).

W polskich studiach nad przekładem literackim niebezpośrednie translacje są jednak wciąż słabo obecne szczególnie w badaniach nad tłumaczeniami literatury polskiej na języki obce. Z uwagi na wspomnianą ,(semi-) peryferyjność" polskiej literatury wiele z jej zagranicznych przekładów jest wynikiem niebezpośrednich praktyk translatorskich - są wśród nich pozycje, które na trwałe weszły do obiegu literackiego w innych krajach (np. angielskie tłumaczenie Solaris Stanisława Lema, dokonane w 1970 roku za pośrednictwem wydania francuskiego i z powodów prawnych wznawiane do dziś; Lem 1970, por. Washbourne 2013: 612). Mimo to w dotychczasowych pracach poświęconych przekładom niebezpośrednim nad faktograficznymi ustaleniami przeważa negatywna ocena zapośredniczonej praktyki translacyjnej jako zwielokrotniającej dystans między tekstem źródłowym i docelowym oraz punktowanie „niedopuszczalnych” rozbieżności. Taka optyka dominuje nawet w skrupulatnym monograficznym studium Andrei Ceccherellego o przekładzie Matki Witkacego, dokonanego przez znaną włoską pisarkę Dacię Maraini za pośrednictwem tłumaczeń sztuki na język francuski i angielski. Autor już w tytule ujmuje akt tłumaczenia niebezpośredniego w cudzysłów: O tym, jak Zamoyski stał się Bourdellem. Witkacy „przettumaczony” przez Dacię Maraini. (Ceccherelli 2012). Wyjątkiem na tym tle są z pewnością publikacje Bożeny Zaboklickiej, która sama jest częścią translatorskiego „tandemu” przekładającego literaturę polską na hiszpański i kataloński, oraz Hanny Pięty, jednej z obecnych liderek międzynarodowych studiów nad przekładem niebezpośrednim, badającej losy recepcji literatury polskiej w Portugalii (m.in. Pięta 2012).

Niniejsze studium ma charakter badawczego rekonesansu i nie rości sobie pretensji do roli całościowego oglądu zagadnienia. Wskazany zakres chronologiczny wynika niewątpliwie z predylekcji badawczych autorki, ale ma też ważniejsze uzasadnienie. Interesujące wydają się bowiem żywotność i akceptacja praktyk niebezpośrednich, utrzymujące się jeszcze w drugiej połowie stulecia, w sytuacji zwiększającej się mobilności społeczeństw (mimo funkcjonowania żelaznej kurtyny), rozwoju filologii uniwersyteckich i dydaktyki języków obcych oraz wzrastającej profesjonalizacji zawodu tłumacza i polityki wydawców uprzywilejowującej tłumaczenie bezpośrednie. Przedstawienie ogólnych wniosków „makrohistorycznych” z nakreśleniem 
precyzyjnych map transferu tekstów wydaje się obecnie przedwczesne, dlatego też, po niezbędnych refleksjach natury terminologicznej i metodologicznej, proponuję dwie „mikrohistorie” przekładów polskich klasyków, które do literatury włoskiej trafiły w wyniku złożonej translacyjnej podróży: tłumaczenia Domu kobiet Zofii Nałkowskiej w przekładzie pisarki Sibilli Aleramo (Nałkowska 2018) i Ferdydurke autorstwa Sergia Miniussiego (Gombrowicz 1961).

\section{Rybka z drugiej ręki. Wyzwania terminologiczne i metodologiczne}

Niezbyt bogata tradycja badań nad translacjami niebezpośrednimi przekłada się na brak ustabilizowanego metajęzyka opisującego zagadnienie. Alexandra Assis Rosa, Hanna Pięta i Rita Bueno Maia wskazują na poznawczy „bałagan” w terminologii odnoszącej się do przekładu niebezpośredniego w języku angielskim i na jej niesatysfakcjonujący rozwój w innych językach, a także na zróżnicowanie i polisemiczność pojęć wynikające z lokalnych i specjalistycznych tradycji badań w obrębie przekładoznawstwa (por. Assis Rosa, Pięta, Bueno Maia 2017 i Pięta 2017: 114-118, w szczególności tabele 1-4). W polskim metajęzyku translatologicznym znajduje odzwierciedlenie typowy, nieco schizofreniczny stosunek do zjawiska przekładu niebezpośredniego, oficjalnie krytykowanego, lecz obecnego w praktyce. Próżno szukać opisujących je terminów w encyklopediach i tezaurusach przekładoznawczych (por. Lukszyn 1998; Dąmbska-Prokop 2000), w których pojawia się natomiast (Lukszyn 1998: 353) pojęcie thumaczenia filologicznego (nazywanego też roboczym lub interlinearnym; Balcerzan 2011: 120), wykorzystywanego jako tekst pośredniczący, którego środowiskowe określenie: „rybka”, na tyle utrwaliło się w polszczyźnie, iż zostało odnotowane przez Słownik Języka Polskiego $P W N^{2}$. W niniejszym studium podążam za wyborami terminologicznymi Assis Rosy, Pięty i Bueno Mai, opartymi na metajęzyku zaproponowanym przez Toury’ego (Toury 1995, zob. też Ringmar 2012: 141), starając się znaleźć dla nich odpowiedniki w polszczyźnie. Termin ,przekład niebezpośredni” (indirect translation), przyjmowany dla oznaczenia całości wieloetapowej procedury translatorskiej, jak również jej ostatecznego rezultatu, pojawia się w polskim tłumaczeniu fragmentu Descriptive Translation Studies and Beyond autorstwa Agaty Sadzy (Toury

2 https://sjp.pwn.pl/szukaj/rybka.html [dostęp: 3.05.2018]. 
2009: 211). Wydaje się, że odpowiada on przyjętej definicji zjawiska lepiej niż inne możliwe spolszczenie angielskiego terminu, „przekład pośredni”, które można odnieść również do translacji pośredniczących (i w takim znaczeniu użyty został w thumaczeniu studium Toury'ego; Toury 2009: 211). Dla poszczególnych etapów procesu przekładowego i uczestniczących w nim języków wyżej wspomniane autorki proponują następujący ciąg pojęciowy: the ultimate source text/language $>$ mediating text/language $>$ ultimate target text/language (Assis Rosa, Pięta, Bueno Maia 2017), który spolszczyć można jako: ,pierwotny tekst/język źródłowy > tekst/język pośredniczący $>$ finalny tekst/język docelowy".

W polskiej literaturze przekładoznawczej w odniesieniu do translacji niebezpośrednich pojawia się też termin ,przekład z drugiej ręki” (por. Balcerzan 2011), proponowany w nowszych anglojęzycznych studiach jako hiponim pojęcia ,przekład niebezpośredni”, umożliwiający oznaczenie stopnia złożoności danej operacji translatorskiej (np. ,przekład z trzeciej ręki”; Assis Rosa, Pięta, Bueno Maia 2017: 117). W międzynarodowych badaniach nad zapośredniczonym tłumaczeniem literackim stosowano również pojęcia „retranslacji”’3 (Gambier 1994) oraz relay (translation). To ostatnie, zapożyczone z terminologii przekładu ustnego (m.in. Dollerup 2000, St André 2009, Ringmar 2012) i dosłownie oznaczające ,przekład sztafetowy”, wypierane jest przez bardziej uniwersalne indirect translation.

Propozycje metodologiczne dotyczące identyfikacji i źródeł wiedzy na temat przekładów niebezpośrednich przedstawiły między innymi Pięta (Pięta 2012) i Maialen Marin-Lacarta (Marin-Lacarta 2017). W przypadku przekładu niebezpośredniego potencjał różnicy, według Theo Hermansa stanowiący istotę tłumaczenia (Hermans 2009), ulega zwielokrotnieniu, co czyni ten rodzaj translacji wyjątkowo ciekawym polem badań przekładoznawczych, niezależnie od przyjętych konceptualizacji i metodologii. Patrząc na nią przez pryzmat niezmiennie inspirujących teorii André Lefevere'a, rzec można, że przechodząc przez kolejne pośredniczące teksty i języki, pierwotny tekst źródłowy ulega następującym po sobie „refrakcjom” (Lefevere 2009), które stają się uprzywilejowanym terenem kulturowych, socjologicznych i imagologicznych analiz. W odniesieniu do transformacji

${ }^{3}$ W polskiej terminologii translatologicznej ,retranslacja” oznacza metodę weryfikacji jakości translacji, polegającą na tłumaczeniu przekładu z powrotem na język wyjściowy (zob. Dąmbska-Prokop 2000: 204-206; Balcerzan 2011: 121).

${ }^{4}$ Małgorzata Tryuk proponowała spolszczenie tego terminu jako ,przekład dwustopniowy" (zob. Tryuk 2007: 54). 
elementów kulturowych w przekładzie niebezpośrednim James Hadley wysuwa (krytykowaną w: Ivaska, Paloposki 2018: 34) hipotezę „efektu konkatenacji” (Hadley 2017), w której dowodzi, że w wyniku wieloetapowej translacji odwołania do pierwotnej kultury źródłowej w finalnym tekście docelowym z reguły znikają lub ulegają zatarciu. Warto jednak zauważyć, że w tekstach pośredniczących i finalnym tekście docelowym „refrakcje” niekoniecznie postępują w kierunku zwiększenia dystansu od oryginału, a rozwiązania translatorskie powstałe $\mathrm{w}$ procesie niebezpośrednim bliższe są niekiedy pierwotnego tekstu źródłowego niż tłumaczenia bezpośrednie (jest to przypadek Ferdydurke w przekładzie Miniussiego, por. Marchesani 1992). Dzieje się tak przykładowo, gdy są one efektem kompilacji tekstów źródłowych lub/i pośredniczących w różnych językach, dziełem zespołu tłumaczy wzajemnie korygujących swoje propozycje, ale również interwencji w formę finalną agentów (np. doradców lub redaktorów) znających pierwotny język źródłowy.

Wyjątkowo uzasadnione wydaje się umieszczenie przekładu niebezpośredniego w perspektywie studiów skoncentrowanych na osobie tłumacza (translator studies) i rozważań nad „sprawczością” (agency) w procesie przekładu (Kinnunen, Koskinen 2010), w której sytuują się poniekąd również wspomniane badania nad ,głosami” w tłumaczeniu. Taki punkt widzenia pozwala dostrzec w finalnym tekście docelowym prawdziwą polifonię głosów, nawarstwiających się w kolejnych etapach przekładowej i wydawniczej podróży oryginału. Różnorodne wypowiedzi agentów zaangażowanych w powstanie translacji niebezpośrednich łączy opowieść o wyjątkowym charakterze takich przekładów i okoliczności, w jakich doszło do ich powstania. Retoryka „szczególnego przypadku” służy zwykle usprawiedliwieniu „grzechu kardynalnego" (Dąbrowska 1955: 194), jakim jest wykonanie przekładu „z drugiej ręki”, ale zwraca też uwagę na zwiększoną „sprawczość" poszczególnych agentów translacji (Ivaska, Paloposki 2018: 34), ich zdecydowanie większe, niż przy bezpośrednich przekładach, zaangażowanie emocjonalne i organizacyjne w powstanie tłumaczeń, które przekłada się na (auto)przyzwolenie na większą autonomię decyzyjną i kreatywność. Przekłady niebezpośrednie rodzą się przecież w szczególnej sytuacji na rynku wydawniczym - gdy brak kompetentnych thumaczy znających pierwotny język źródłowy lub gdy ograniczenia prawne bądź polityczne zmuszają do poszukiwania niestandardowych rozwiązań (zob. Washbourne 2013: 611-612). Pojawiają się też jako wynik młodzieńczej „lekkomyślności” (Dąbrowska 1955: 194), powstają z sentymentu do konkretnego dzieła 
literackiego lub w rezultacie fascynacji nim, z potrzeby kontroli nad formą artystyczną lub przesłaniem tekstu (Gombrowicz 2004: 115), z troski o walory estetyczne, a zarazem prestiż dzieła w kulturze docelowej, w końcu z przyczyn prozaicznych - z powodu presji czasowej i pobudek finansowych (np. we Włoszech autorzy przekładów przeznaczonych do wystawienia na scenie otrzymują dodatkowe wynagrodzenie z Società Italiana degli Autori ed Editori, dlatego zwykle zlecano je osobom z kręgów teatralnych, niekoniecznie znającym pierwotny język źródłowy; zob. Raffo 1994: 80). Za przekładami niebezpośrednimi stoją więc najczęściej dostosowane do szczególnych okoliczności decyzje wydawnicze oraz złożone osobiste i estetyczne motywacje, które należy rozpatrywać indywidualnie, rekonstruując „mikrohistorie” tłumaczy i przekładów (Paloposki 2017). Ogrom wiedzy na ten temat skrywają archiwa, wciąż w niewielkim stopniu wykorzystywane w badaniach translatologicznych (por. Munday 2014). Włoskie przekłady Domu kobiet i Ferdydurke przywołuję w niniejszym artykule z uwagi na „Szczególne okoliczności” ich powstania, ale też bogaty materiał archiwalny, częściowo niepublikowany, który rzuca ważne światło na okoliczności i sam proces kreacji obu tekstów. Dokumenty związane z niedawno wydanym przekładem Aleramo, La casa delle donne (Nałkowska 2018), znajdują się w archiwum pisarki zdeponowanym w Fondazione Gramsci w Rzymie. Liczne materiały źródłowe dotyczące przekładu Ferdydurke na język włoski, a zwłaszcza przekładów pośredniczących na hiszpański i francuski, dostępne są w druku od dawna (m.in. Gombrowicz 1998, Gombrowicz 2004). W niniejszym studium ich uzupełnienie stanowi nieznana korespondencja z prywatnego archiwum Sergia Miniussiego, przechowywanego w Archivio di Stato w Trieście.

\section{La casa delle donne}

Sibilla Aleramo pracowała nad tłumaczeniem Domu kobiet Zofii Nałkowskiej od początku 1931 roku, który otwierał w historii literatury włoskiej słynną „dekadę przekładów”. Translatorski boom lat 30. związany był zarówno z intensywnym rozwojem rynku wydawniczego we Włoszech i odkryciem komercyjnego potencjału przekładów (zwłaszcza tłumaczeń anglosaskiej literatury popularnej), jak i z funkcjonowaniem faszystowskiej cenzury (zob. m.in. Rundle 2010). W tych warunkach działalność translatorska jawiła się wielu pisarzom jako pewne źródło dochodu i przestrzeń 
relatywnej twórczej wolności oraz szansa stworzenia politycznej i intelektualnej alternatywy dla oficjalnej kultury faszyzmu. Naturalnie spora część tłumaczeń w tym okresie powstała z pozakomercyjnych i pozaideologicznych pobudek, będąc wynikiem autentycznego zainteresowania literaturami spoza Italii - lata międzywojenne między innymi to czas kształtowania się ośrodków włoskiej slawistyki i aktywnej działalności, również translatorskiej, jej wybitnych przedstawicieli (jak Ettore Lo Gatto czy Renato Poggioli; por. Mazzitelli 2016).

Udział translacji niebezpośrednich we włoskim boomie przekładowym był znaczący: niemal standardem stało się wówczas funkcjonowanie przekładowych tandemów, w których jeden z tłumaczy był najczęściej natywnym użytkownikiem języka źródłowego lub filologiem, a drugi zawodowym literatem. Niektórzy z tych ostatnich lekceważyli lub ukrywali wkład współpracowników w powstanie przekładów. Emblematyczna jest w tym kontekście postać Lucii Rodocanachi, przyjaciółki Elia Vittoriniego i Eugenia Montalego, tłumaczki literatury anglosaskiej i niemieckiej oraz autorki wielu przekładów pośredniczących dla firmowanych przez znanych przyjaciół translacji. Jej nazwisko zostało pominięte między innymi w kultowej antologii współczesnej prozy amerykańskiej Americana (1940) opublikowanej pod redakcją Vittorniego, choć aktywnie uczestniczyła w selekcji i translacji tekstów (zob. Aveto 2006).

Już dawno zauważono korelację między praktyką przekładu niebezpośredniego a stosunkiem do obcości w przekładzie: liczba translacji niebezpośrednich rośnie, gdy w danym okresie historycznym, lokalnej lub gatunkowej tradycji translatorskiej istnieje nacisk na dostosowanie tekstu docelowego do norm kultury przyjmującej (Ringmar 2012: 143). Typowe dla modernizmu postrzeganie przekładu jako kreatywnego zawłaszczenia będącego przedłużeniem twórczości oryginalnej oraz interpretacyjnego narzędzia, które pozwala spojrzeć na dzieła dawnych i obcych literatur przez pryzmat własnych zainteresowań ideologicznych i estetycznych (Yao 2016: 215), uprzywilejowywało translacje zorientowane na akceptowalność, które często miały (ukrywany lub jawny) niebezpośredni charakter. Do takich translacji należy La casa delle donne, chociaż autorka przekładu w deklaracjach była zwolenniczką „uniżonej wierności” przekładu wobec poetyki tłumaczonego autora, któremu nie wolno narzucać „własnego tonu i gustu" (Aleramo 1997: 158).

Aleramo usłyszała o debiucie scenicznym Nałkowskiej, wystawionym po raz pierwszy w Teatrze Polskim w Warszawie w marcu 1930 roku, od 
swojej polskiej przyjaciółki, Emilii Szenwic, warszawskiej dziennikarki i tłumaczki, właścicielki willi w Positano, gdzie włoska pisarka chętnie spędzała wakacje. Sztuka, w której ,na scenie nie ma ani jednego mężczyzny, i nawet pies (...) nie jest psem, ale suczką" (Słonimski 1982: 171), osiągnęła wielki sukces w Polsce i wzbudziła zainteresowanie twórców i impresariów teatralnych z wielu krajów. Gdy Szenwicowa, autorka „Bluszczu”, „Tygodnika Ilustrowanego”, „Kobiety Współczesnej”, mająca spore kontakty w kulturalnym środowisku Warszawy, zwróciła się do Nałkowskiej z zapytaniem o możliwość dokonania przekładu na włoski, okazało się, że gotowa jest już translacja autorstwa bliżej nieznanej Marii Poznańskiej. Nałkowska, nie bez wahań (Nałkowska 1988: 218), zleciła jednak Aleramo wykonanie autorskiej „,korekty” istniejącego tłumaczenia i scedowała na nią prawo wyboru wykonawcy sztuki we Włoszech ${ }^{5}$. Decyzja ta była najpewniej wynikiem troski o estetyczne walory przekładu i poziom włoskiej inscenizacji: w Dziennikach Nałkowska nie raz daje upust rozczarowaniu pracą tłumaczy swoich utworów na języki obce ${ }^{6}$. W liście do Sibilli z 21 listopada 1930 roku polska autorka wyjaśnia, że „każde tłumaczenie na język obcy dokonane przez Polaka musi zostać poprawione przez pisarza, potrzebuje swoistego «wygładzenia» - co na szczęście panna Poznańska bardzo dobrze zrozumiała"7. A zatem zdawało się, że zaangażowanie Aleramo, którą Nałkowska pamiętała jako twórczynię autobiograficznej feministycznej powieści Kobieta (w Polsce publikowanej w odcinkach na łamach „Prawdy” w latach 1909-1910; zob. Kłos 2015a), gwarantowało satysfakcjonujący poziom artystyczny tekstu i wybór ambitnego wykonawcy. Ta intuicja okazała się słuszna: La casa delle donne jest tekstem literacko znakomitym. W kwestii inscenizacji zabiegi włoskiej pisarki, ostatecznie nieudane, koncentrowały się na pozyskaniu do współpracy uznanych kompanii teatralnych Lamberta Picassa, członka zespołu Luigiego Pirandella i Tatiany Pawłowej, pionierki reżyserii na Półwyspie Apenińskim (Kłos 2015: 120-122). Jakie były natomiast motywacje Sibilli? Jako pisarka od początku literackiej kariery poszukiwała ona odrębnej kobiecej estetyki i zdawała sobie sprawę

5 „Pani Nałkowska ucieszyła się, że będzie miała taką znaną tłumaczkę jak nasza piękna Sibilla! Opowiadałam o Tobie bardzo długo, z największym możliwym entuzjazmem" (list Szenwicowej do Aleramo z 14 listopada 1930, cyt. za: Kłos 2015: 116).

${ }^{6}$ „Wobec cech mego pisania, mej chytrej, trochę złośliwej prostoty - tłomacz musi być przynajmniej równie inteligentny jak ja" (Nałkowska 1988: 294).

${ }^{7}$ Fondazione Gramsci, Fondo Aleramo (dalej cytowane jako FA), serie 2: „Corrispondenza” - „Sezione cronologica”, sygn. 62/585/350. 
z transgresywnej mocy słowa wypowiadanego w teatrze. Tłumaczyła rzadko, przy wyborze tekstów kierując się zasadą ,wdzięczności i wspólnoty poglądów” oraz „duchowego pokrewieństwa” z autorem oryginału (Aleramo 1997: 158). Jak się wydaje, w Domu kobiet zaintrygował ją koncept sztuki bez mężczyzn, niespotykana koncentracja kobiecego głosu na scenie, co jest interesujące w kontekście polskiego odbioru sztuki, krytykowanej w środowiskach kobiet postępowych i ocenianej jako antyfeministyczna czy wręcz antykobieca. Takie wytłumaczenie motywacji Aleramo potwierdza pośrednio list pisarki do Emilii z marca 1931 roku, odnaleziony przez spadkobierców Szenwicowej:

W kwestii tłumaczeń, przy których wspaniałomyślnie oferujesz mi współpracę, pragnę cię uprzedzić, że niezmiernie trudno doprowadzić do wystawienia sztuk teatralnych (teatr we Włoszech jest w sytuacji tragicznej!), o ile nie są to arcydzieła. Być może uda mi się to w przypadku La Casa delle Donne, gdyż sztuka, w której wszystkie postaci to kobiety, może wzbudzić ciekawość. Ale to potrwa miesiące, a może i kwartały ${ }^{8}$.

Ciekawe jest również, że według umowy zawartej listopada 1930 roku Aleramo, odpowiedzialna oficjalnie za ,wygładzenie” przekładu, miała otrzymać wyższe wynagrodzenie niż właściwa tłumaczka: przypaść jej miało $30 \%$ środków z tytułu wystawienia sztuki, wobec $20 \%$ dla Poznańskiej. Dla rozwiania ewentualnych wątpliwości Nałkowska przesłała włoskiej autorce La maison des femmes przekład sztuki na język francuski przygotowywany z myślą o wystawieniu w Paryżu (Domem kobiet zainteresował się Nikołaj Jewreinow, słynny dramatopisarz, reżyser i teoretyk teatru), a firmowany przez „świetną artystkę” Thérèse Koerner, cenioną tłumaczkę literatury polskiej na język francuski, współpracowniczkę „Wiadomości Literackich” i francuskojęzycznych czasopism kulturalnych wydawanych w Polsce (Nałkowska 1988: 160 i 171-172).

Zachowane w archiwum Aleramo rękopis La casa delle donne i przekłady pośredniczące pozwalają na precyzyjną rekonstrukcję procesu translatorskiego, który okazał się dużo bardziej złożony niż zakontraktowane „wygładzenie” istniejącego przekładu Poznańskiej. Na karcie tytułowej rękopisu Aleramo umieściła nazwiska swoje i Poznańskiej, ale taka atrybucja

${ }^{8}$ Archiwum prywatne rodziny Yazbecków, list Sibilli Aleramo do Emilii Szenwic z 6 III [1931]. Wyróżnienia autorki. Panu Dany’emu Yazbeckowi dziękuję serdecznie za udostępnienie dokumentu. 
autorstwa nie odzwierciedla stanu faktycznego. Włoska pisarka stworzyła bowiem kompilacyjną wersję zestawioną $\mathrm{w}$ równych mniej więcej proporcjach z fragmentów tłumaczenia na język polski, przeniesionych bez poprawek lub ze stylistycznymi i językowymi modyfikacjami oraz z fragmentów przetłumaczonych na język włoski za pośrednictwem francuskiego przekładu Koerner. O ile początkowe strony przekładu Aleramo podążają za przekładem Poznańskiej, o tyle w kolejnych głównym źródłem staje się tłumaczenie Koerner. Zaznaczyć należy, że oba przekłady pośredniczące reprezentują skrajnie różne podejścia do problemu obcości. Poznańska, ze względu na własną ograniczoną kreatywność w języku włoskim i pod wpływem ciążenia autorytetu podziwianej Nałkowskiej, proponuje rozwiązania translatorskie nakierowane na tekst źródłowy. Przekład Koerner jest z kolei wersją silnie udomawiającą, „oczyszczoną” z elementów obcości, które mogłyby okazać się niezrozumiałe dla docelowego odbiorcy, a zarazem skracającą część scen i dialogów. Zredukowano w niej lub zmieniono wszelkie odwołania do kultu katolickiego, postfeudalnej rzeczywistości polskiej wsi, nazwy typowo polskich zwyczajów i potraw. Opierając się na obu translacjach, Aleramo przygotowała własną kompilacyjną wersję tekstu, którą poddała dalszej literackiej obróbce: zbliżyła przekład do własnej poetyki, przesyconej liryzmem i skupionej na grze emocji. Ciekawe są przesunięcia modyfikujące obraz niektórych postaci sztuki, z którymi - jak się wydaje - włoska pisarka utożsamiała się w szczególny sposób. Taką postacią jest Babka: w tekście Nałkowskiej i przekładach pośrednich całkowicie uzależniona od pomocy młodszych krewnych - fizyczna niedołężność jest przeciwwagą dla reprezentowanej przez nią duchowej siły i mądrości starej prorokini. Pomijając część didaskaliów, Aleramo czyni z niej postać bardziej samodzielną, jeszcze mocniejszą. Przykładem może być scena śniadania Babki:

\section{BABKA}

(siedzi nieruchomo, patrzac nigdzie, poważna, czarno ubrana, z ciemna twarza, czeka bez niecierpliwości)

MARIA

Już, już jest śniadanie.

(przysuwa blizej stolik, rozklada talerzyki)

Tu bułka, tu miód. Masło już rozsmarowane.

\section{BABKA}

Dobrze, dziecko. Ja widzę, widzę. Idź już, jedz. 
MARIA

$($ siada $)$

Trochę mamie pomogę.

(z uśmiechem $)^{9}$

(Nałkowska 1990: 19-20)

Sibilla ją mocno skróciła, sugerując się wersją tłumaczki na język francuski. Radykalny skrót Koerner uzupełniła frazami zaczerpniętymi z przekładu Poznańskiej ${ }^{10}$, eliminując jednak odniesienia do czynności wykonywanych przez Marię w związku z obsługą staruszki oraz jej kwestie, w których wyraża się zrytualizowana troska:

La nonna rimane immobile nella sua poltrona, seria senza impazienza, lo sguardo fisso nel vuoto. Rientra Maria, recando un vassoio con la colazione.

MARIA

Ecco, ecco il pane, il burro, il miele. Ti aiuterò un poco, mamma.

(si siede, sorride)

(Nałkowska 2018: 44-45).

W wyniku tych zabiegów zmienia się również percepcja postaci Marii, która u Nałkowskiej za fasadą przesadnej operatywności skrywa żal o nieudane życie osobiste.

\section{Ferdydurke}

Pierwszy włoski przekład Ferdydurke z 1961 roku to tekst o wyjątkowo złożonej historii, która - mimo licznych poświęconych mu opracowań, koncentrujących się głównie na szczegółowych translatorskich wyborach (m.in.

9 „La nonna / (siede immobile, lo sguardo fisso nel vuoto, seria, vestita di nero, attende senz'ombra d'impazienza) / Maria / Ecco, ecco la colazione. (avvicina il tavolino, dispone i piattini) Ecco, qua il pane, qua il miele. Il burro è già spalmato". Z. Nałkowska, $L a$ casa delle donne, przeł. M. Poznańska, maszynopis w FA, serie 3: „Scritti”, sottoserie 3: „Traduzioni”, UA 34, fol. 19 (zacytowano z zachowaniem oryginalnej formy stylistycznej, ortografii i interpunkcji).

10 ,/L'aïeule se tient immobile dans son fauteuil - Marie entre apportant sur un plateau le petit déjeuner./ / MARIE / Je vais vous aider, Maman”. Z. Nałkowska, Le maison des femmes, przeł. T. Koerner, maszynopis w FA, serie 3: „Scritti”, sottoserie 3: „Traduzioni”, UA 34, fol. 19. 
Marchesani 1992; Łukaszewicz 2004; Surma-Gawłowska 2004) - wciąż nie została w pełni opowiedziana ani z punktu widzenia krytyki genetycznej tekstu, ani z perspektywy badań nad sprawczością w przekładzie. Sergio Miniussi (1932-1991), pochodzący z Triestu poeta, thumacz i dziennikarz kulturalny, przyjaciel i redaktor wydań prozy Umberta Saby (m.in. Ernesta, Saba 1975), pracował, opierając się na pośredniczącym przekładzie francuskim (Gombrowicz 1958), będący efektem współpracy Gombrowicza i Rolanda Martina (przekład podpisał pseudonimem Brone), francuskiego dziennikarza poleconego mu przez dyrekcję Instytutu Francuskiego w Buenos Aires, który z kolei bazował na przekładzie powieści na język hiszpański z 1947 roku (Gombrowicz 1947).

To hiszpańskie tłumaczenie, powstające od końca 1945 i przez kilka miesięcy 1946 roku - dzieło samego Gombrowicza i Komitetu Tłumaczy, grupy młodych literatów rezydujących w Buenos Aires, wśród których znaleźli się Kubańczycy, pisarz Virgilio Piñera i tłumacz Humberto Rodríguez Tomeu oraz argentyński filozof Alejandro Rússovich (późniejszy główny współtłumacz Ślubu) ${ }^{11}$ - jest zapewne najsłynniejszym przekładem niebezpośrednim w dziejach recepcji polskiej literatury i jedną z najbardziej niezwykłych translatorskich współpracy w historii. Wielokrotnie wspominane i analizowane (Gombrowicz 2004: 69-119; Suchanow 2017: 11-32, Kurek 2004) obrosło prawdziwą legendą, stając się nawet tematem powieści (Pariani 2006). Tłumacze pracowali w nieszablonowy sposób: z dala od „smutnych pracowni producentów książek” (Gombrowicz 2004: 98), w sali kawiarni Rex, mieszkaniu Kubańczyków, w pensjonacie Luxor, bez słowników. Gombrowicz, który swój ówczesny hiszpański przyrównał do „kilkuletniego dziecka, które ledwo umie mówić”, przygotowywał etapami wstępną wersję przekładu z polskiego i nad tą wersją potem żarliwie debatowano przy stoliku tłumaczy w poszukiwaniu odpowiednich słów. Praca nad przekładem Ferdydurke była zatem nie tylko procesem literackim, ale też ważnym doświadczeniem międzyludzkim. Dla samego Gombrowicza wejściem w lokalną bohemę, a za sprawą Piñery i Tomeu, jawnych homoseksualistów, przeżyciem o zabarwieniu wręcz erotycznym ${ }^{12}$.

11 Gombrowicz miał być dumny, że „Joyce miał czterech tłumaczy, a on dwudziestkę" (Suchanow 2017: 25).

12 W Kronosie pod datą 1946 autor zanotował: „Rozmowy w Reksie - kolacje w Luxorze - i u Kubańczyków. Cygańsko-literackie życie. (...) Kubańczycy wytwarzają silnie erotyczną atmosferę, ale koncentruję się bardziej na literaturze" (Gombrowicz 2013: 54). 
W pracy z Rolandem Martinem Gombrowicz powtórzył w pewnym zakresie opisaną powyżej metodę. Martin fragmentami, na podstawie wersji hiszpańskiej przygotowywał „brulion”, następnie drobiazgowo konsultowany z Gombrowiczem, poprawiany i znów konsultowany. Przekład powstawał w Rexie (gdzie swoje uwagi dorzucali bywalcy, dawni członkowie Komitetu Tłumaczy), w mieszkaniu Gombrowicza, ale głównie w domu Martina, który z powodu przeciągających się niemal do rana posiedzeń nad tekstem miewał ,pewne kłopoty rodzinne” (Gombrowicz 2004: 117). Przyczyny zaangażowania autora w proces przekładu Martin upatrywał w potrzebie kontroli przekazu: „Ferdydurke jest dziełem bardzo prywatnym i niekonwencjonalnym. Co linijka czyha niebezpieczeństwo, że się jego sens wypaczy. To dlatego Gombrowicz nalegał na swój udział w tłumaczeniu na francuski, tak jak w przypadku tłumaczenia na hiszpański” (Gombrowicz 2004: 115). Ferdydurke to także debiut Gombrowicza na kolejnych rynkach wydawniczych, decydujący o dalszej ścieżce kariery: stąd jego szczególna troska o jakość i literackie niuanse tekstu (,niuanse tłomaczeniowe to diablo subiektywna sprawa i mnie doświadczenie nauczyło, iż nikomu w tym nie można ufać", Gombrowicz 1998: 15; zob. też Suchanow 2017: 26-32).

W korespondencji z Konstantym A. Jeleńskim, pośredniczącym w kontaktach z paryskim wydawcą książki, jej gorliwym promotorem i autorem wstępu do wersji francuskiej, Gombrowicz uparcie bronił rozwiązań osobiście wypracowanych z tłumaczami, niekiedy ekstrawaganckich stylistycz$n^{1 e^{13}}$ oraz - ku rozczarowaniu Kota - odbiegających od pierwotnego tekstu źródłowego w języku polskim (por. Gombrowicz 1998: 15-23).

Gdy pod koniec 1958 roku Gombrowicz negocjował z wydawnictwem Einaudi publikację Ferdydurke we Włoszech, Jeleński wpierw pisał o „oczywistej” w kontekście przyszłego przekładu kolaboracji Włocha z Polakiem, a następnie zasugerował sprawdzoną już ścieżkę: „Może byłoby zresztą najlepiej, gdybyś to przetłumaczył w Buenos Aires z jakimś Włochem (przecież jest ich tam masę) z hiszpańskiego" (Gombrowicz 1998: 36 i 38). Pomysł ten jednak nie został zrealizowany, być może dlatego, że wydawnictwu początkowo zależało na przekładzie z polskiego oryginału (w innych włoskich wydawnictwach publikujących dzieła Gombrowicza w latach 60., między

${ }^{13}$ Martin wspomina: „Jeśli przyszłoby mi tłumaczyć Ferdydurke samemu, byłbym dużo ostrożniejszy. A w rezultacie bardziej niezgrabny, bardziej mdły i płaski” (Gombrowicz 2004: 117). 
innymi w mediolańskiej oficynie Feltrinelli, zdecydowano się właśnie na przekłady bezpośrednie). Ze strony Einaudi za książkę Gombrowicza odpowiadał najpierw pracujący jako redaktor u turyńskiego wydawcy wybitny pisarz Italo Calvino. Jeleński w liście z 22 stycznia 1959 roku donosił:

Calvino pisze mi, że Einaudi jest zdecydowany na publikację, tylko nie mogą znaleźć tłumacza z polskiego. Zasugerowałem, by do współpracy przy włoskim przekładzie wciągnąc Gustawa Herlinga, ale on odmówił. Wtenczas zaproponowałem Calvino rzecz następującą: mieszka w Paryżu młody poeta włoski, bardzo zdolny, Sergio Miniussi. Uwielbia on Twoje pisarstwo i bardzo pragnąłby przełożyć Ferdydurke we współpracy ze mną. Wyglądałoby to tak: pracowałby na tekście francuskim i hiszpańskim, kolacjonując wraz ze mną każdy rozdział z oryginałem polskim. Wydaje mi się to najlepszym rozwiązaniem (Gombrowicz 1998: 51-52).

Miniussi studiował w Paryżu literaturę porównawczą, publikując korespondencje kulturalne we włoskiej prasie, głównie w triesteńskim „Il Piccolo", i współpracując z lokalnym radiem RAI. Jeleński poznał go dzięki swojej partnerce Leonor Fini, pochodzącej z Triestu malarce i scenografce, której „młody poeta” zarekomendowany został przez wspólną znajomą, Anitę Pittoni, animatorkę życia literackiego w Trieście, artystkę, projektantkę, pisarkę i wydawczynię (debiutancki tom poetycki Miniussiego La gioia è dura z 1958 roku ukazał się w oficynie Edizioni dello Zibaldone, kierowanej przez Pittoni; zob. Parmegiani 1995). Umowa na przekład Ferdydurke nosi datę 27 kwietnia 1959 i daje czas thumaczowi do końca roku ${ }^{14}$. W czerwcu Miniussi pisał z Paryża do Pittoni:

Tłumaczę dla Einaudi (...) polską książkę. (...)

Jestem zajęty przekładem i dlatego każda poprawka oznacza dla mnie niewiarygodną stratę czasu. (...) I jestem zmęczony, fizycznie. Jednak nie odpuszczam. Tak naprawdę brakuje mi posiłków, o które sam nie muszę się troszczyć. Ale po przyjeździe do domu wszystkie drobne obowiązki (zakupy, pranie, prasowanie, czynsz) znikną i będę mógł cały dzień poświęcać pracy. To był ciężki rok. Nie mogę zatrzymać się w domu dłużej niż do połowy września. Potem muszę zacząć korektę polskiej książki z Kotem Jeleńskim. (...) Mam nadzieję, że dzięki tym thumaczeniom zarobię niewielką sumkę, która pozwoli mi na rzeczy, na jakie dotąd nie było mnie stać. Walka o każdy grosz bywa czasami

${ }_{14}$ Archivio di Stato di Trieste, Fondo Sergio Miniussi (cytowane dalej jako FSM), sygn. 631 . 
wykańczająca: trzeba rezygnować z różnych okazji, gdyż brak środków materialnych, aby spotkać się z jednym lub drugim w restauracji na przykład. A tutaj wszyscy mają manię spotykania się w takiej kawiarni (120 franków za kawę) czy w innej restauracji! Nie chcę wiele, bo na pieniądzach mi szczególnie nie zależy, chodzi jedynie o kwotę, dzięki której da się spokojnie przeżyćc ${ }^{15}$.

Choć Gombrowicz musiał wyrazić zgodę na zatrudnienie Miniussiego, z listów do Jeleńskiego wywnioskować można, że nie najlepiej znosił brak możliwości bezpośredniego nadzoru nad procesem przekładu:

Einaudi pisze, że Ferdy przekłada pod Twoją kontrolą. Mam nadzieję, że perfect władasz włoskim i że skrupulatnie a też surowo rozpatrzysz początek - w razie czego pisz zaraz do Einaudi, żeby on skontrolował. To musiałby właściwie przejrzeć jakiś literat włoski pur sang. Napisałem do Einaudi, że jest nieodzowne sprawdzić należycie możliwości tego tłumacza przed powierzeniem mu całości (Gombrowicz 1998: 59)

Jeleński i Miniussi mieli też najwyraźniej inne niż autor wyobrażenie o stopniu koniecznego zaangażowania Kota w tworzenie przekładu. Tłumacz, zapewne z powodów rodzinnych ${ }^{16}$, nie powrócił do Paryża jesienią 1959 (zob. Gombrowicz 1998: 71), choć jeszcze w sierpniu potwierdzał z Kotem umówioną na wrzesień osobistą współpracę przy translacji ${ }^{17}$. Ukończył przekład samodzielnie i w grudniu, przed oddaniem wydawcy, przesłał go Jeleńskiemu do zaopiniowania. Z 4 stycznia 1960 roku pochodzi list Kota, w którym ów wyraża się z uznaniem o pracy Miniussiego:

Twój przekład uważam ogólnie za doskonały. Znalazłeś właściwy ton, prawdziwy ekwiwalent stylu Gombrowicza. Twoje rozwiązania językowe są inteligentne i poetyckie. Sądzę, że możesz przesłać książkę do Einaudi. Chciałbym ponownie przeczytać twój rękopis z polskim tekstem w ręku ${ }^{18}$.

Trudno zrozumieć, dlaczego Gombrowicz już po tym zaatakował wydawcę za niedotrzymanie zobowiązań dotyczących tłumaczenia, przypominając o warunku kontroli Jeleńskiego nad tekstem ${ }^{19}$. I pomimo komplementów Kota, który naniósł na przekład jedynie „garść poprawek” (Gombrowicz

\footnotetext{
15 FSM, sygn. 413.

${ }^{16}$ FSM, sygn. 418.

17 FSM, sygn. 1605.

18 FSM, sygn. 1605.

19 FSM, sygn. 1659.
} 
1998: 71), oraz zadowolenia redakcji (po Calvinie, przebywającym w Stanach Zjednoczonych na stypendium Fundacji Forda, opiekę nad książką przejął Luciano Foà, przyszły założyciel wydawnictwa Adelphi), która po Ferdydurke zaproponowała Miniussiemu kolejne thumaczenia (m.in. Podglądacza Alaina Robbe-Grilleta) i zainteresowała się jego oryginalnymi utworami ${ }^{20}$, entuzjastą włoskiej wersji swojej powieści nie został. Po otrzymaniu egzemplarzy książki, która ukazała się ostatecznie w 1961, napisał w Kronosie: „Przychodzi Ferdy włoska - katastrofalnie wydana” (Gombrowicz 2013: 104).

\section{Podsumowanie}

Dwie powyższe „mikrohistorie”, choć zarysowane skrótowo, zapowiadają szerokie spektrum problemów związanych z przekładem niebezpośrednim oraz złożoność i „nielinearność” takich operacji translatorskich, które stają się cennym dokumentem międzynarodowych intelektualnych kontaktów. Obie potwierdzają „oczywistość” i akceptowalność zapośredniczonych translacji zarówno w polskiej, jak i włoskiej kulturze literackiej XX wieku, wyrastając z podobnego przekonania Nałkowskiej i Gombrowicza, że absolutnie priorytetowa jest artystyczna doskonałość i kreatywność przekładu, zdolna stworzyć właściwe wyobrażenie o twórczości autora pierwotnego tekstu źródłowego (pojmowane raczej w kategoriach kultury docelowej) i zapewnić mu sukces na obcym rynku wydawniczym. W obu przypadkach widać też wyraźnie, że zaplanowany przez autorów oryginału i usankcjonowany umową scenariusz translatorski niekoniecznie realizowany jest przez tłumaczy oraz innych agentów przekładu w finalnym tekście docelowym. W przypadku Ferdydurke ciekawa jest rola Konstantego A. Jeleńskiego, niekryjącego się z przywiązaniem do przedwojennej polskiej wersji tekstu, od której sam Gombrowicz zdystansował się w wykreowanych we współpracy z innymi przekładach na hiszpański i francuski.

Wyczerpująca analiza roli przekładów niebezpośrednich w polsko-włoskich stosunkach literackich wymaga dalszych studiów bibliograficznych i źródłowych. Bogactwo materiału, złożoność stojących za nim historii autorskich i tekstowych, zapowiada fascynujące wyzwanie badawcze.

${ }^{20}$ FSM, sygn. 1658-1659. 


\section{Bibliografia}

Aleramo S. 1997. La Principessa di Clèves, w: S. Aleramo, Andando e stando, a cura di R. Guerricchio, Milano: Feltrinelli, s. 158-161.

Alvstad C. 2017. Arguing for indirect translations in twenty-first-century Scandinavia, „Translation Studies” 10(2), s. 150-165.

Alvstad C., Greenall A.K., Jansen H., Taivalkoski-Shilov K. 2017. Introduction: Textual and Contextual Voices of Translation, w: C. Alvstad, A.K. Greenall, H. Jansen, K. Taivalkoski-Shilov (eds.), Textual and Contextual Voices of Translation, Amsterdam-Philadelphia: John Benjamins, s. 3-20.

Assis Rosa A., Pięta H., Bueno Maia R. 2017. Theoretical, Methodological and Terminological Issues Regarding Indirect Translation: An Overview, „Translation Studies” 10(2), s. 113-132.

Aveto A. 2006. Traduzioni d'autore e no. Elio Vittorini e la „segreta” collaborazione con Lucia Rodocanachi, w: Contorbia F. (a cura di), Lucia Rodocanachi: le carte, la vita, Firenze: Società Editrice Fiorentina, s. 153-192.

Balcerzan E. 2011. Ttumaczenie jako ,wojna światów”. W kręgu translatologii i komparatystyki, Poznań: Wydawnictwo Naukowe UAM.

Ceccherelli A. 2012. O tym, jak Zamoyski stat się Bourdellem: Witkacy ,przettumaczony” przez Dacię Maraini, „Roczniki Humanistyczne” 60(1), s. 31-52.

Dąbrowska M. 1955. Parę myśli o pracy przekładowej, w: M. Rusinek (red.), O sztuce tłumaczenia, Wrocław: Zakład Narodowy imienia Ossolińskich, s. 193-206.

Dąmbska-Prokop U. (red.). 2000. Mała encyklopedia przekładoznawstwa, Częstochowa: Educator.

D'hulst L. 2010. Translation History, w: Y. Gambier, L. van Doorslaer (eds.), Handbook of Translation Studies, Amsterdam-Philadelphia: John Benjamins, s. 397-405.

Dollerup C. 2000. Relay and Support Translations, w: A. Chesterman, N. Gallardo, Y. Gambier (eds.), Translation in Context: Selected Contributions from the EST Congress, Amsterdam: John Benjamins, s. 17-26.

Gambier Y. 1994. La retraduction, retour et détour, „Meta” 39(3), s. 413-417.

Gombrowicz R. 2004. Gombrowicz w Argentynie. Świadectwa i dokumenty, Kraków: WL.

Gombrowicz W. 1947. Ferdydurke: novela, Buenos Aires: Argos.

- 1958. Ferdydurke: roman, trad. Brone, Paris: René Julliard.

1961. Ferdydurke, trad. S. Miniussi, Torino: Einaudi.

1967. Il matrimonio, trad. R. Guidieri, Torino: Einaudi.

1968. La operetta, trad. J. Morteo, G.R. Morteo, Torino: Einaudi.

1998. Walka o sławę. Korespondencja, cz. 2, W. Gombrowicz, K. Jeleński, F. Bondy, D. de Roux, układ i przedmowy J. Jarzębski, Kraków: WL.

2013. Kronos, Kraków: WL.

Heilbron J. 2010. Structure and Dynamics of the World System of Translation, International Symposium ,Translation and Cultural Mediation”, UNESCO H.Q., February 22-23, 2010. http://portal.unesco.org/culture/en/files/40619/12684038723Heilbron. pdf/Heilbron.pdf [dostęp: 15.09.2017]. 
Hadley J. 2017. Indirect Translation and Discursive Identity: Proposing the Concatenation Effect Hypothesis, „Translation Studies” 10(2), s. 183-197.

Herling-Grudziński G. 1958. Un mondo a parte, trad. G. Magi, Bari: Laterza.

Hermans T. 2009. Przektad, zadrażnienie i rezonans, przeł. M. Heydel, w: P. Bukowski, M. Heydel (red.), Wspótczesne teorie przektadu. Antologia, Kraków: Znak, s. 297-311.

Ivaska L., Paloposki O. 2018. Attitudes towards Indirect Translation in Finland and Translators'Strategies: Compilative and Collaborative Translation, „Translation Studies" 11(1), s. 33-46.

Jansen H., Wegener A. 2013. Multiple Translatorship, w: Jansen H., Wegener A. (eds.), Authorial and Editorial Voices in Translation: Collaborative Relationships between Authors, Translators, and Performers, Québec: Éditions québécoises de l'œuvre,https://yorkspace.library.yorku.ca/xmlui/bitstream/handle/10315/26642/ YS\%20AEV1\%20Jansen\%20and\%20Wegener.pdf?sequence=1\&isAllowed=y [dostęp: 30.04.2018].

Kapuściński R. 1991. L'imperatore: caduta di un autocrate, trad. M.L. Bocchino, C. de Magri, Milano: Serra e Riva.

Kinnunen T., Koskinen K. 2010. Introduction, w: T. Kinnunen, K. Koskinen, Translators' Agency, Tampere: Tampere University Press, s. 4-10.

Kłos A. 2015. La casa delle donne. Sulla storia della traduzione italiana di „Dom kobiet” di Zofia Natkowska, ,pl.it / rassegna italiana di argomenti polacchi” VI, s. 107-123.

— 2015a. Tradurre il femminismo. Sulla traduzione polacca di „Una donna” di Sibilla Aleramo, „Kwartalnik Neofilologiczny” LXII(2), s. 257-265.

Kłos A. 2018. Salvatore Quasimodo, traduttore di Adam Mickiewicz. Sull'importanza degli archivi letterari per gli studi sulla traduzione, „Quaderni del '900” XVIII, s. 75-86.

Krall H., Edelman M. 1985. Il ghetto di Varsavia: memoria e storia dell'insurrezione, przeł. M. Meghnagi, Roma: Città nuova.

Kurek M. 2004. „Ferdydurke” po hiszpańsku (kilka uwag o autorskim przektadzie Gombrowicza), w: E. Skibińska (red.), Gombrowicz i tlumacze, Łask: Leksem, s. 11-20.

Lefevere A. 2009. Ogórki matki Courage. Tekst, system i refrakcja w teorii literatury, przeł. A. Sadza, w: P. Bukowski, M. Heydel (red.), Wspótczesne teorie przekładu. Antologia, Kraków: Znak, s. 224-246.

Lem S. 1963. Gli esploratori dell'astro ignoto, trad. G. Uccelli, Milano: Baldini e Castoldi.

— 1970. Solaris, trans. J. Kilmartin, S. Cox, London: Faber and Faber.

1995. Cyberiade, trad. R. Valla, Milano: Mondadori.

Lukszyn J. (red.). 1998. Tezaurus terminologii translatorycznej, Warszawa: PWN.

Łukaszewicz J. 2004. Szkoła we włoskich przekładach „Ferdydurke”, w: E. Skibińska (red.), Gombrowicz i thumacze, Łask: Leksem, s. 67-83.

Marchesani P. 1992. D'una edizione „critica” di Gombrowicz (e d'altro), „Europa Orientalis" 11(2), s. 233-294.

(a cura di). 1994. La letteratura polacca contemporanea in Italia. Itinerari d'una presenza. Studi in memoria di Marina Bersano Begey, Roma: La Fenice. 
Marchesani P. 1994a. La narrativa polacca in Italia negli anni 1945-1990, w: P. Marchesani (a cura di). 1994. La letteratura polacca contemporanea in Italia. Itinerari d'una presenza. Studi in memoria di Marina Bersano Begey, Roma: La Fenice, s. 15-33.

Marin-Lacarta M. 2017. Indirectness in Literary Translation: Methodological Possibilities, „Translation Studies” 10(2), s. 133-149.

Mazzitelli G. 2016. Le pubblicazioni dell'Istituto per l'Europa orientale. Catalogo storico (1921-1944), Firenze: Firenze University Press.

Miłosz C. 1955. La mente prigioniera, trad. O. Ceretti Borsini, Milano: A. Martello.

Munday J. 2014. Using Primary Sources to Produce a Microhistory of Translation and Translators: Theoretical and Methodological Concerns, „The Translator” 20(1), s. 64-80.

Nałkowska Z. 1944. L'amore cattivo, trad. M. Rakowska, E. Fabietti, Milano-Verona: Mondadori.

- 1988. Dzienniki IV: 1930-1939, t. 1, red. H. Kirchner, Warszawa: Czytelnik. 1990. Dom kobiet. Sztuka w trzech aktach, w: Z. Nałkowska, Utwory dramatyczne, Warszawa: Czytelnik.

2018. La casa delle donne, trad. S. Aleramo, a cura di A. Kłos, Pisa: Pacini Editore. Paloposki O. 2017. In Search of an Ordinary Translator: Translator Histories, Working Practices and Translator-Publisher Relations in the Light of Archival Documents, „The Translator” 23(1), s. 31-48.

Pariani L. 2006. Gombrowicz i Buenos Aires: historia pewnego przekładu, przeł. K. Żaboklicki, WL.

Parmegiani S. 1995. Far libri: Anita Pittoni e lo Zibaldone, Trieste: Parnaso.

Pięta H. 2012. Patterns in (In)directness: An Exploratory Case Study in the External History of Portuguese Translations of Polish Literature (1855-2010), „Target” 24(2), s. 310-337.

2017. Theoretical, Methodological and Terminological Issues in Researching Indirect Translation: A Critical Annotated Bibliography, ,Translation Studies” 10(2), s. $198-216$.

Quasimodo S. 1956. Il falso e vero verde: con un discorso sulla poesia, Milano: Mondadori, s. 49-52.

- 1961. Poezje, red. i słowo wstępne A. Międzyrzecki, Warszawa: PIW.

Ringmar M. 2012. Relay Translation, w: Y. Gambier, L. van Doorslaer (eds.), Handbook of Translation Studies, t. 3, Amsterdam-Philadelphia: John Benjamins, s. 141-144.

Raffo A.M. 1994. Qualche considerazione sulla presenza della letteratura drammatica polacca in Italia nei tempi recenti, w: P. Marchesani (a cura di). 1994. La letteratura polacca contemporanea in Italia. Itinerari d'una presenza. Studi in memoria di Marina Bersano Begey, Roma: La Fenice, s. 73-86.

Rundle C. 2010. Publishing Translations in Fascist Italy, Oxford: Peter Lang.

Saba U. 1975. Ernesto, Torino: Einaudi.

Słonimski A. 1982. Gwałt na Melpomenie, Warszawa: Wydawnictwa Artystyczne i Filmowe.

St André J. 2009. Relay, w: M. Baker, G. Saldanha (eds.), Routledge Encyclopedia of Translation Studies, London-New York: Routledge, s. 230-232. 
Strożek P. 2012. Marinetti i futuryzm w Polsce 1909-1939: obecność - kontakty - wydarzenia, Warszawa: IS PAN.

Stryjkowski J. 1984. Austeria, trad. A. Kurczab, P. Statuti, Roma: E/o.

Suchanow K. 2005. Argentyńskie przygody Gombrowicza, Kraków: WL.

2017. Gombrowicz. Ja, geniusz, Wołowiec-Warszawa: Czarne-Muzeum Literatury im. Adama Mickiewicza.

Surma-Gawłowska M. 2004, „Ferdydurke” po włosku, czyli Gombrowicz okietznany, w:

E. Skibińska (red.), Gombrowicz i thumacze, Lask: Leksem, s. 61-68.

Toury G. 1995. Descriptive Translation Studies and Beyond, Amsterdam-Philadelphia: John Benjamins.

2009. Metoda opisowych badań przekładu, przeł. A. Sadza, w: P. Bukowski, M. Heydel (red.), Wspótczesne teorie przekładu. Antologia, Kraków: Znak, s. 206222.

Tryuk M. 2007. Przekład ustny konferencyjny, Warszawa: Wydawnictwo Naukowe PWN.

Vasari R. [1926]. Udręka maszyn, przeł. I. Krzywicka, Muzeum Teatralne w Warszawie, sygn. 1401.

Washbourne K. 2013. Nonlinear Narratives: Paths of Indirect and Relay Translation, „Meta” 58(3), s. 607-625.

Witkiewicz S.I. 1970. Commedia ripugnante di una madre, trad. D. Maraini, Roma: Bulzoni.

Yao S.G. 2016. Translation Studies and Modernism, w: J.-M. Rabaté (ed.), A Handbook of Modernism Studies, Oxford: Wiley-Blackwell, s. 209-223.

Zaboklicka B. 2006. Nowe odczytanie ,Ślubu” Witolda Gombrowicza w świetle przekładu autorskiego na hiszpański, w: M. Czermińska, K. Meller, P. Fliciński (red.), Literatura, kultura i język polski w kontekstach i kontaktach światowych, Poznań: Wydawnictwo Naukowe, s. 265-275.

2013. Praktyka i dydaktyka thumaczenia literackiego w dwujęzycznym ,tandemie”, „Między Oryginałem a Przekładem” 19-20, s. 141-151. 